\title{
HUBUNGAN ANTARA LEVEL EMERGENCY SEVERITY INDEX (ESI) DENGAN KEPUASAN PASIEN DI INSTALASI GAWAT DARURAT RUMAH SAKIT SIDO WARAS
}

\author{
RELATIONSHIP BETWEEN EMERGENCY SEVERITY INDEX (ESI) LEVEL WITH PATIENT SATISFACTION AT \\ SIDO WARAS HOSPITAL EMERGENCY DEPARTEMENT \\ Regina Kurniasari \\ Fakultas Kesehatan Masyarakat, Universitas Airlangga Surabaya \\ E-mail: reginakurniasari10@gmail.com
}

\begin{abstract}
The number of patients in Sido Waras Hospital Emergency Department declined since in 2013 until 2015 and the preliminary survey also showed there were complex complaints emergency department services. Therefore, the purpose of this study was to analyze the relationship between the service and the satisfaction of patients in Sido Waras Hospital Emergency Department.The concept of ESI Sido Waras Hospital Emergency Department namely provided categories of patients based on the gravity and duration of patient management. Therefore in this study to analyze the relationship with the ESI level of patient satisfaction in the Sido Waras Hospital Emergency Department. This study was a survey (observe-sectional study). By using simple random sampling technique, obtained 86 respondents and spearman test to see their relationship with the ESI level of patient satisfaction. The results obtained that there was no relationship between the level of ESI with patient satisfaction $(p=0.147)$ suggesting that patients with category esi esi 1 through 5 do not have a relationship with patient satisfaction. There were no relation among satisfaction patient with ESI level.
\end{abstract}

Keywords : Emergency department, ESI level, patient satisfaction, service quality

\section{PENDAHULUAN}

Rumah sakit sebagai pelayanan kesehatan bagi masyarakat memiliki kewajiban untuk terus meningkatkan kualitas pelayanannya. Pelayanan yang diberikan rumah sakit kepada pasien nantinya akan mempengaruhi apakah pasien akan datang kembali ke rumah sakit tersebut atau pindah ke rumah sakit lain akibat tidak merasa puas atas layanan yang diberikan rumah sakit terhadap pasien.

Pelayanan yang bersifat intangible merupakan hal yang tidak terlihat namun besar dampaknya bagi pasien. IGD merupakan pintu utama masuknya pasien yang mengalami gawat darurat menjadikan kunci bagi sebuah pelayanan di rumah sakit. Pelayanan Instalasi Gawat Darurat (IGD) memiliki perbedaan dengan pelayanan lainnya. Pada IGD, pasien ditangani dan dilayani tidak berdasarkan antrian atau nomor urut seperti halnya pelayanan yang ada di poli maupun dokter umum ataupun pada puskesmas.

Pelayanan IGD mengacu pada konsep triage dimana pasien akan dilayani berdasarkan tingkat kegawat daruratannya. Secepat apapun pasien datang ke IGD, namun masih ada kondisi pasien lain yang lebih gawat, maka IGD akan memprioritaskan pasien yang kondisinya lebih gawat daripada pasien yang datang dahulu tersebut. Hal ini terkadang akan membuat pasien lain merasa adanya ketidak adilan pada pelayanan IGD Rumah Sakit tersebut.

Setiap Rumah Sakit memiliki konsep triage yang berbeda-beda. Salah satu konsep triage yang dapat digunakan yaitu Emergency Severity Index (ESI) atau Australian Triage Scale (ATS). ESI merupakan dasar yang digunakan dalam pengelompokkan pasien berdasarkan tingkat kondisi keparahan atau kegawatdaruratannya. ATS juga 
merupakan dasar pengelompokkan pasien pada IGD, namun pengelompokkan ATS lebih pada lama waktu pasien dapat menunggu untuk ditangani (Guidelines on the Implementation of ATS in Emergency Department, 2013). Terdapat 5 level pada ESI atau ATS.

Pasien pada level 1 yaitu pasien dengan tingkat kegawatan yang tinggi sehingga jika tidak mendapatkan penanganan saat itu juga, maka akan mengancam jiwa pasien. Pada pasien level 1 dengan penanganan 0 menit sehingga pasien harus ditangani pada saat pasien datang ke IGD. Pasien pada level 2,3,4 dan 5 masing-masing memilki waktu maksimal penanganan yaitu 10 menit, 30 menit, 60 menit, dan 120 menit (Guidelines on the Implementation of ATS in Emergency Department, 2013).

Menurut Esther (2009) terdapat peningkatan sebesar 25\% waktu tunggu pada IGD yaitu dari 46,5 menit menjadi 58,1 menit. Sehingga dengan semakin lamanya waktu tunggu pada IGD, semakin banyak keluhan pada sejumlah pasien IGD.
Pengelompokkan pasien berdasarkan response time nya, terdapat keluhan pada pasien level 4 dan 5 karena pada pasien di level 4 dan 5 biasanya mendapatkan pelayanan dengan waktu yang lama (Esther and Bhuiya, 2009)

Sejumlah pasien IGD mengeluh atas lamanya penanganan yang diberikan petugas karena pasien dikategorikan pada level ESI dengan waktu pelayanan yang masih dapat ditoleransi (Jerrard, 2012).

Konsep triage masih banyak belum dipahami oleh pasien. Dimana pasien yang ditangani terlebih dahulu merupakan pasien pada level ESI 1 (mengancam jiwa), membuat pasien dengan keadaan yang tidak terlalu gawat mengeluh terhadap waktu pelayanan yang diberikan (Bhuiya,2009).

Pada IGD Rumah Sakit Sido Waras, terdapat penurunan jumlah kunjungan pasien IGD Rumah dari tahun ke tahun, yaitu pada tahun 2013 hingga tahun 2015. Berdasarkan data rumah sakit Sido Waras dari tahun 2013 hingga tahun 2015, angka kunjungan terus menurun seperti tabel 1.

Tabel 1. Jumlah Kunjungan Pasien IGD Rumah Sakit Sido Waras tahun 2015

\begin{tabular}{lrrr}
\hline \multirow{2}{*}{ TRIMESTER } & \multicolumn{3}{c}{ JUMLAH KUNJUNGAN IGD } \\
\cline { 2 - 4 } & TH. 2013 & TH.2014 & TH.2015 \\
\hline I & 3611 & 3577 & 3190 \\
II & 3777 & 3281 & 2697 \\
III & 3321 & 3080 & 2544 \\
\hline TOTAL & 10709 & 9938 & 8431 \\
\hline
\end{tabular}

Sumber data: Laporan tahunan IGD Rumah Sakit Sido Waras

Terdapat penurunan kunjungan pasien IGD di Rumah Sakit Sido Waras yang ditunjukkan pada tabel 1. Total kunjungan pasien pada tahun 2013 yaitu sebesar 10709 pasien menurun sebesar 7,19\% menjadi 9938 pasien di tahun 2014. Total kunjungan pasien pada tahun 2014 menurun hingga 15,1\% menjadi 8431 pada tahun 2015. 
Menurunnya kunjungan pasien di IGD Rumah Sakit Sido Waras Mojokerto mengindikasikan adanya ketidakpuasan pasien terhadap pelayanan IGD Rumah Sakit Sido Waras. Setelah dilakukan survei awal mengenai apa saja keluhan yang dirasakan oleh pasien, maka didapatkan hasil bahwa sebagian besar pasien mengeluh terhadap lamanya waktu tunggu dalam pelayanan IGD sebesar $66,67 \%$. Beberapa responden menyatakan bahwa lama waktu tunggu pelayanan IGD Rumah Sakit Sido Waras dapat berkisar hingga 30 menit sampai 1 jam. Dan total keseluruhan pelayanan yang ada di IGD sebesar 53,33\% mengalamin ketidakpuasan.

Keluhan atas lamanya waktu tunggu di IGD Rumah Sakit Sido Waras berkaitan dengan penetapan level ESI atau triage. Hal ini dikarenakan pasien dilayani terlebih dahulu berdasarkan level ESI nya. Pasien dengan kondisi kritis akan diberikan pelayanan terlebih dahulu dibanding dengan pasien batuk pilek. Hal ini membuat sejumlah pasien mungkin mengalami ketidakpuasan pelayanan IGD karena kurang pemahaman tentang triage ESI. Oleh karena itu penelitian ini memiliki tujuan yaitu untuk mengetahui apakah terdapat hubungan antara level ESI dengan Kepuasan pasien di IGD Rumah Sakit Sido Waras.

\section{PUSTAKA}

Kepuasan pasien merupakan nilai subyektif pasien terhadap pelayanan yang diberikan setelah membandingkan dari hasil pelayanan yang diberikan dengan harapannya. Pasien akan merasa puas jika pelayanan yang diberikan sesuai harapan pasien atau bahkan lebih dari apa yang diharapkan pasien (Goestsch dan S.Davis, 2005).

Stresser 1991 dalam Supriyanto dan Ratna (2010), mendefinisikan patients satisfaction is conceptually defined as patient's value judgements and subsequent reactions to the stimuli they perceive in the health care environment just before, during and after the course of their inpatient stay or clinic visit. These value judgements and reactions will be influenced by the dispositional characteristics of patients and their previous life and health care experiences.

Strasser dalam Supriyanto dan Ratna (2010), juga menyatakan bahwa kualitas pelayanan adalah layanan yang dirasakan tanpa membandingkan dengan harapan konsumen. Hal ini terjadi karena konsumen untuk menilai secara objektif terhadap sebuah stimulus tanpa memiliki informasi awal (product, service, knowledge) yang cukup. Dalam Supriyanto dan Ratna (2010), dijelaskan model kepuasan analisis teori kepuasan baik Strasser.

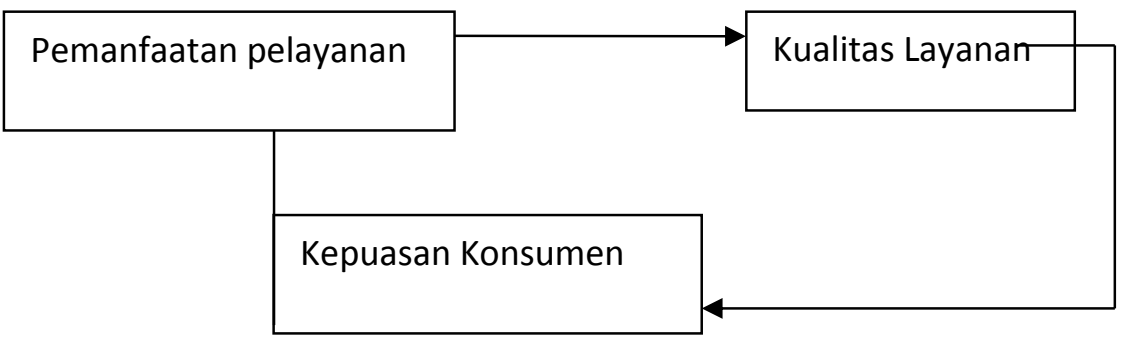

Gambar 1. Teori Kepuasan Dvaid Strasser (Supriyanto dan Ratna, 2010) 
Intalasi Gawat Daurat (IGD) rumah sakit adalah salah satu bagian di rumah sakit yang menyediakan penanganan awal bagi pasien yang menderita sakit dan cedera, yang dapat mengancam kelangsungan hidupnya. IGD rumah sakit mempunyai tugas menyelenggarakan pelayanan asuhan medis dan asuhan keperawatan sementara serta pelayanan pembedahan darurat, bagi pasien yang datang dengan gawat darurat medis. Pelayanan pasien gawat darurat adalah pelayanan yang memerlukan pelayanan segera, yaitu cepat, tepat dan cermat untuk mencegah kematian dan kecacatan. Salah satu indikator mutu pelayanan adalah waktu tanggap (Depkes RI, 2006).

Instalasi Gawat Darurat merupakan pelayanan yang ada di rumah sakit yang dibutuhkan oleh pasien dalam rangka menyelamatkan jiwanya. Konsep IGD ini didasarkan pada waktu pelayanannya. Waktu merupakan hal terpenting pada IGD karena sangat berkaitan dengan penyelamatan jiwa pasien. Kemampuan rumah sakit dalam menangani pasien dapat dilihat dari bagaimana rumah sakit memberikan pelayanannya di IGD rumah sakit tersebut (Kelly, 2005).

Konsep IGD berfokus pada sistem triage atau pngelompokkan pasien berdasarkan kondisi keparahan kesakitannya. Di Indonesia, beberapa rumah sakit menggunakan konsep triage dengan melihat pada triage di negara USA yaitu menggunakan ESI.
Emergency Severity Index

dikembangkan sejak akhir tahun sembilan puluhan di Amerika Serikat. Sistem ESI bersandar pada perawat dengan pelatihan triage secara spesifik. Pasien yang masuk digolongkan dalam ESI 1 sampai ESI 5 sesuai pada kondisi pasien dan sumber daya rumah sakit yang diperlukan oleh pasien (Christ, 2010). ESI akan lebih mudah diterapkan di Indonesia karena tidak ada batas waktu spesifik yang ditentukan secara ketat untuk masing-masing level. Selain itu, ESI tidak secara spesifik mempertimbangkan diagnosis untuk penentuan level triage (Mace dan Mayer 2008).

Penerapan ESI di Indonesia sangat cocok karena perawat triage lebih mudah melihat kondisi dan keparahan dibandingkan bekerja sama dengan dokter menegakkan diagnosis. Perawat triage bersama dokter jaga akan lebih mudah melihat keparahan kondisi dan mempertimbangkan sumber daya apa saja yang akan digunakan untuk menangani pasien tersebut. Menghitung response time juga merupakan pekerjaan sederhana yang tidak mudah dilakukan di IGD. Ketiadaan ketentuan waktu kapan pasien harus dijumpai oleh dokter menambah daya pikat sistem triage. Sistem triage ESI mempergunakanskala nyeri 1-10, sama dengan yang secara umum dipakai di Indonesia (Bolk,2007). 


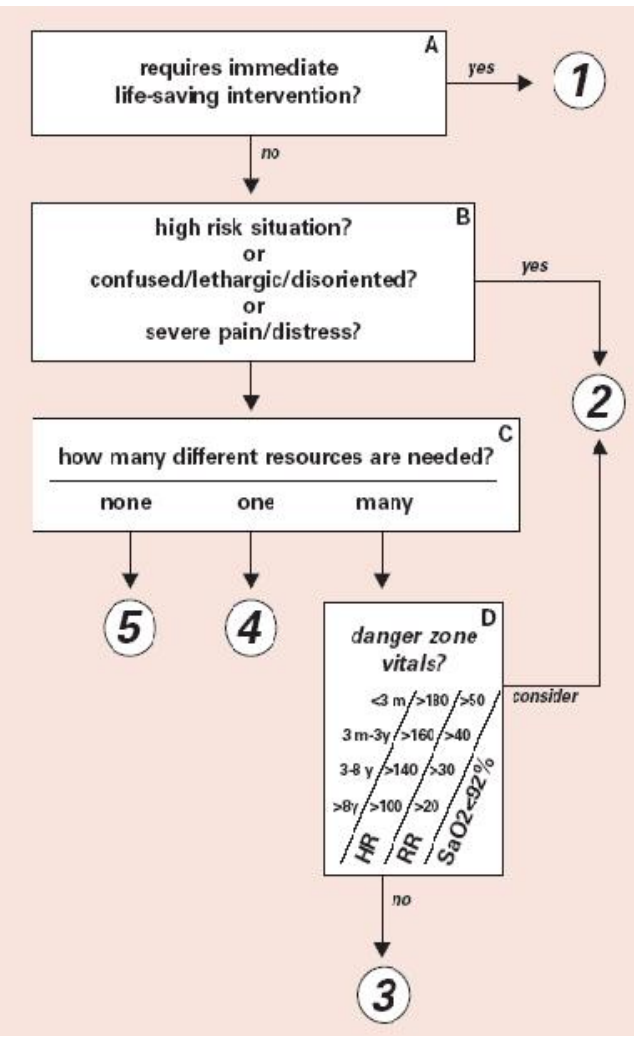

Gambar 2. Logaritma ESI (ESI Triage Research Team, 2004)

Emergency Severity Index (ESI) merupakan konsep baru triage yang menggunakan lima skala dalam pengklasifikasian pasien di IGD. Dalam pengaplikasiannya, saat perawat bertemu dengan pasien pertama kali, harus dapat segera melakukan penilaian kondisi pasien dan memberikan keputusan akhir perawatan, pemulangan atau pemindahan ke ruang perawatan (Bolk et al, 2007). Penerapan ESI ini dikembangkan oleh US Emergency Departement dimana angka hospitalisasi dapat diprediksi dengan jelas melalui ESI. Penerapan ESI ini melihat pemeriksaan diganostic yang kemungkinan dibutuhkan oleh pasien.

Triage ESI bersandar pada lima dasar (Gilboy et al, 2011). Pertama , apabila pasien memerlukan intervensi penyelamatan jiwa maka pasien akan masuk dalam ESI 1. Apabila pasien tidak bisa menunggu karena resiko tinggi, perubahan kesadaran akut , atau nyeri hebat makan pasien akan masuk dalam ESI 2. Apabila pasien memerlukan lebih satu sumber daya maka pasien masuk dalam ESI 3. Namun, apabila pasien memerlukan sumberdaya lebih hanya satu maka pasien masuk dalam ESI 4. Dan apabila pasien bisa menunggu karena resiko tidak tinggi, tidak terjadi perubahan kesadaran akut atau nyeri hebat maka pasien masuk ke dalam ESI 5.

$$
\text { Untuk kategori ESI } 2 \text { dan ESI } 3
$$

mensyaratkan perawat triage untuk mengetahui secara tepat berapa sumber daya yang diperlukan. Sumber daya yang dimaksud adalah utilisasi yang akan direncanakan dokter IGD terhadap pasien tersebut. Contoh sumber daya adalah pemeriksaan darah dan urine di laboratorium, pencitraan, pemberian cairan intravena, nebulisasi, pemasangan kateter urine, dan penjahitan luka laserasi. Pemeriksaan darah, urine, dan sputum yang dilakukan bersamaan hanya dihitung satu sumber daya. Demikian pula bila ada CT Scan kepala, foto polos thorax, dan foto polos ekstremitas yang dilakukan bersamaan dihitung sebagai satu sumber daya (Gilboy,2011).

Perkiraan penggunaan sumber daya oleh perawat triage ini memerlukan pemahaman perawat triage terhadap standar pelayanan dan apa yang biasa dilakukan dokter pada IGD tersebut (Gilboy,et al 2011). Jumlah sumber daya yang direncanakan bisa bervariasi sesuai besar,kelengkapan, dan standar pelayanan IGD tersebut. Pasien dengan kasus yang sama bisa saja dikategorikan pada ESI 
yang berbeda pada dua IGD rumah sakit yang berbeda.

Pada sistem ESI terdapat bagian tersendiri mengenai triage pada anak-anak. Bagian ini memberikan petunjuk yang jelas mengenai apa saja yang akan diperiksa ketika melakukan triage pasien anak-anak. Inilah yang tidak dijumpai pada sistem triage lain (Triage Research Team,2004).

\section{METODE}

Penelitian ini bersifat survey (obervasi sectional),karena ditinjau dari metodenya dilakukan pada populasi besar maupun kecil dengan mengunakan data sampel yang diambil dari populasi (Sugiyono, 2010). Dan apabila ditinjau dari pendekatan, penelitian ini merupakan penelitian cross sectional karena peneleitian ini dilakukan dalam satu tahapan atau satu periode waktu (Arikunto, 2006). Penelitian dilaksanakan pada bulan Mei 2015. Populasi sasaran dalam penelitian ini adalah semua pasien IGD Rumah Sakit Sido waras yang berjumlah 2544. Sedangkan besar sampel yang digunakan adalah sebanyak 86 responden. Pengambilan sampel ini menggunakan metode simple random sampling, sehingga diperoleh sampel sebanyak 86 dari seluruh total populasi.

Instrumen yang digunakan dalam penelitian ini adalah kuesioner yang terdiri dari pertanyaan karakteristik faktor pasien yang meliputi usia, jenis kelamin, pekerjan, pengalaman berobat, dan status rujukan. Pertanyaan juga memuat tentang pelayanan yang ada di IGD yang meliputi penetapan level ESI dan kepuasan pasien. Pengumpulan data primer diperoleh dari hasil wawancara dan pembuatan kuesioner.

Penyajian data berupa tabel secara deskriptif dan secara statistik. Faktor pasien dan peralatan IGD disajikan secara deskriptif sedangkan level ESI dan kepuasan pasien disajiakan secara statistik.

Pengukuran level ESI pasien dapat ditentukan oleh petugas, sehingga petugas IGD khusus untuk mengisi kolom kuisioner kategori ESI pasien. Sedangkan untuk pengukuran kepuasan pasien, terdapat 5 skor yaitu 1 untuk nilai sangat tidak puas, 2 untuk nilai tidak puas, 3 untuk nilai netral, 4 untuk nilai puas, dan 5 untuk nilai sangat puas. Pengisian kuisioner dapat diisi oleh pasien yang bersangkutan maupun keluarga pasien (apabila pasien tidak memungkinkan untuk mengisi kuisioner).

Uji yang digunakan untuk mengetahui hubungan antara level ESI dengan kepuasan pasien yaitu uji spearman karena dalam hal ini level ESI dan kepuasan pasien memiliki skala data ordinal.

\section{HASIL DAN PEMBAHASAN}

Kategori ESI pada IGD sebagian besar responden di IGD Rumah Sakit Sido Waras dikategorikan pada ESI 5 sebanyak 43 pasien dengan presentase $50 \%$.Pelayanan pasca IGD, didapatkan sebagian besar responden di IGD Rumah Sakit Sido Waras mendapatkan pelayanan pasca IGD rawat jalan sebanyak 50 orang dengan presentase $58,1 \%$.

Terdapat beberapa ruang yang ada di IGD seperti ruang penerimaan dan ruang tindakan. Pada 
ruang penerimaan terdapar ruang administrasi, ruang triage dan ruang penyimpanan stretcher. Pada ruang tindakan, ruang resusitasi, ruang bedah dan ruang non bedah dijadikan satu. Pada ruang penerimaan semua alat sudah lengkap berdasarkan pedomanan bangunan IGD Kementerian Kesehatan RI Tahun 2012. Namun pada ruang resusitasi, masih ada beberapa alat yang tidak lengkap. Beberapa alat seperti nasopharingeal tube, chest tube, Cricotyrotom, Long spine belum terdapat di ruang IGD. Beberapa alat seperti Laringoscope set anak, dewasa, Laryngeal Mask Airway, endotracheal tube berada di ruang anastesi

Ventilator Transport yang seharusnya terdapat di IGD, berada di ruang ICU. Pada ruang bedah semua peralatan lengkap. Namun pada ruang non bedah masih belum terdapat opthalmoscope. Untuk ruang anak, pada IGD Rumah Sakit Sido Waras berada menjadi satu dengan ruang NICU dan ruang kebidanan berada jadi satu dengan poli.

Level ESI dan Kepuasan Pasein
Dalam konsep Instalasi gawat darurat, terdapat pengelompokkan pasien berdasarkan tingkat kegawatan kesakitan pasien. ESI atau Emergency Severity Index merupakan patokan yang dipakai oleh Amerika untuk menentukan prioritas mengenai kegawat daruratan pasien. ESI dibagi menjadi 5 yaitu ESI 1 sampai dengan ESI 5. Pasien dengan ESI 1 merupakan pasien yang jika tidak mendapatkan pelayanan dengan segara akan mengancam nyawanya. Contohnya yaitu pasien dengan kecelakaan yang sangat parah tidak sadarkan diri serta kekurangan darah. ESI 2 yaitu pasien dengan resiko tinggi terdapat beberapa rasa nyeri dan terdapat perubahan dalam kesadaran. ESI 3 yaitu pasien dengan resiko tidak terlalu tinggi namun membutuhkan lebih dari 1 penanganan khusus seperti tes urin dan jahit luka. ESI 4 sama dengan ESI 3 namun pasien hanya membutuhkan 1 penanganan khusus seperti photo torax. ESI 5 yaitu pasien yang tidak beresiko dan dapat menunggu dalam pelayanannya seperti panas, batuk, pilek, pusing.

Tabel 2. Distribusi Responden menurut Level ESI di IGD Rumah Sakit Sido Waras Bulan Mei Tahun 2016

\begin{tabular}{lrrr} 
& ESI & \multicolumn{2}{c}{ Frekuensi } \\
\cline { 2 - 4 } & & $\mathbf{N}$ & $\%$ \\
\hline ESI 1 & 5 & 5,8 \\
\hline ESI 2 & 5 & 5,8 \\
\hline ESI 3 & 10 & 11,6 \\
\hline ESI 4 & 23 & 26,7 \\
\hline ESI 5 & 43 & 50 \\
\hline Total & 86 & 100 \\
\hline
\end{tabular}

Berdasarkan tabel 3 diketahui bahwa sebesar 23,2 $\%$ responden yang mengalami tingkat kegawat daruratan yang tinggi. Hal ini terlihat dari besarnya
ESI 1 sampai dengan ESI 3 dimana terjadi tingkat kegawatan yang sangat tinggi. Pada ESI 5 adalah ESI yang paling banyak dialami oleh responden yaitu 
sebesar $50 \%$. Hal ini menunjukkan bahwa dalam konsep IGD tidak hanya yang memiliki kondisi parah yang dapat dilayani. Penyakit ringan seperti panas, batuk, pilek yang tergolong pada ESI 5 pun juga

masuk

IGD.

Tabel 3. Tabulasi Silang ESI dengan lama waktu tunggu di IGD Rumah Sakit Sido Waras Bulan Mei Tahun 2016

\begin{tabular}{lllllr}
\hline Lama waktu/ESI & $\mathbf{1}$ & $\mathbf{2}$ & $\mathbf{3}$ & $\mathbf{4}$ & $\mathbf{5}$ \\
\hline 0 & 4 & - & - & - & - \\
\hline 5 & 1 & - & - & - & - \\
\hline 10 & - & 4 & 2 & 6 & 4 \\
\hline 20 & - & 1 & 5 & 5 & 10 \\
\hline 30 & - & - & 2 & 6 & 8 \\
\hline 40 & - & - & - & 4 & 7 \\
\hline 50 & - & - & 1 & - & 3 \\
\hline 60 & - & - & - & - & 1 \\
\hline 70 & - & - & - & 1 & 1 \\
\hline 80 & - & - & - & - & 3
\end{tabular}

Sejumlah 86 pasien IGD, terdapat 5 pasien pada ESI 1. Pasien dilayani pada menit ke 0 sebanyak 4 pasien, dan 1 pasien di menit ke 5 . Pada ESI 2 terdapat 5 pasien. sebanyak 4 pasien dilayani pada menit ke 10 dan 1 pasien dimenit ke 20 . Terdapat sebanyak 10 pasien di ESI. 2 pasien dilayani pada menit ke 10,5 pasien pada menit 20,2

Tabel 4. Kepuasan Pasien atas keseluruhan pelayanan di IGD Rumah Sakit Sido Waras Bulan Mei Tahun 2016

\begin{tabular}{lrr}
\hline $\begin{array}{c}\text { Kepuasan pasien } \\
\text { terhadap } \\
\text { keseluruhan } \\
\text { pelayanan IGD }\end{array}$ & $\mathbf{N}$ & \multicolumn{2}{c}{ Frekuensi } \\
\cline { 2 - 3 } & 5 & 5,8 \\
\hline Tidak Puas & 11 & 12,8 \\
\hline Kurang Puas & 30 & 34,9 \\
\hline Netral & 25 & 29,1 \\
\hline Puas & 15 & 17,4 \\
\hline Sangat Puas & 86 & 100 \\
\hline Total & &
\end{tabular}

Tabel 4 merupakan gambaran atas kepuasan pasien terhadap seluruh pelayanan yang dirasakan selama berada di IGD Rumah Sakit Sido pasien di menit ke 30, dan 1 pasien di menit ke 50 . Terdapat 23 pasien pada ESI 4. Sebanyak 1 pasien dilayani pada menit ke 10, 6 pasien pada menit ke 20, 5 pasien di menit ke 30, 6 pasien dimenit ke 40,4 pasien dimenit ke 50, dan 1 pasien dimenit ke 80 . Terdapat 23 pasien pada ESI 5 dan paling banyak pasien ditangani pada menit ke 30 .

Waras. Modus atau frekuensi terbanyak yaitu sebesar $34,9 \%$ terletak pada kategori netral. Dengan banyaknya pasien yang menyatakan netral, bukan ada puas atau sangat puas, hal ini menunjukkan bahwa ini menjadi masalah.

Sebesar 5,8\% pasien menyatakan tidak puas atas pelayanan yang diberikan oleh IGD, namun sebagian besar pasien menyatakan puas terhadap pelayanan di IGD sebesar $29 \%$. Pasien yang menyatakan kurang puas sebesar $12,8 \%$. Dan hanya17,4\% yang menyatakan sangat puas atas pelayanan IGD Rumah Sakit Sido Waras. 


\section{Hubungan Kepuasan dengan Level ESI}

IGD Rumah Sakit Sido Waras tidak menggunakan ESI yang berasal dari Amerika , namun menggunakan konsep triage dari Australian Triage atau ATS Triage. ATS memiliki konsep yang sama dengan ESI dengan menggunakan 5 skala prioritas. Namun perbedaan ESI dan ATS terletak pada cara dasar pengklasifikasiannya. Jika ESI mengklasifikasikan pasien berdasarkan diagnostic yang kemungkinan dibutuhkan pasien, dalam ATS pengklasifikasian pasien berdasarkan lama pasien dapat menunggu untuk mendapatkan perawatan di IGD (Gilboy et al, 2011).

Dalam konsep ATS, skala 1 sampai dengan 5 menunjukkan respon time petugas. Level 1 yaitu unstable, dimana reponse time petugas yaitu 0 (Immediate), yang artinya pasien harus ditangani saat itu juga. Level 2 yaitu threatned, dimana response time petugas yaitu dalam beberapa menit maksimal 10 menit. Level 3 yaitu maksimal pasien ditangani dalam waktu 30 menit. Dan level 4 dan 5 yaitu penanganan pasien masing-masing dapat ditunda hingga 60 menit dan 120 menit.

Dalam penelitian ini, sejumlah 86 responden yang tergolong level 1 yaitu sebanyak 5 pasien, level 2 sebanyak 5 pasien, level 3 sebanyak 10 pasien, level 4 sebanyak 23 pasien, dan level 5 sebanyak 43 pasien. Sehingga dapat dikatakan dalam penelitian ini sebagian besar merupakan pasien dengan level stable, dimana penanganannya dapat ditunda.

Sebanyak 5 orang pasien di level 1 sebagian besar merupakan pasien kritis akibat kecelakaan dimana jika tidak ditangani saat itu juga akan mengancam nyawanya. Pasien dengan level 2 merupakan pasien dengan ciri penyakit lethargic dengan kesadaran menurun. Sehingga sebanyak 5 orang yang berada pada level 2 harus segera mendapatkan penanganan dalam waktu 5 menit hingga maksimal 10 menit.

Sedangkan 10 pasien pada level 3, pada IGD Rumah Sakit Sido Waras sebagian besar merupakan pasien dengan ciri-ciri demam, detak jantung serta nafas yang cepat. Penanganannya paling lambat yaitu 30 menit. Contohnya yaitu penyakit penyakit seperti meningitis, usus buntu, pneumonia.

Pasien dengan level 4 dan level 5 di IGD Rumah Sakit Sido Waras merupakan pasien yang penanganannya dapat ditunda. Pasien pada level 4 maksimal paling lambat mendapatkan penanganan dalam waktu 60 menit dan maksimalpaling lambat pasien di level 5 mendapat penanganan dalam waktu 120 menit. Biasanya pasien pada level 4 dan 5 hanya mengalami gangguan kesehatan yang ringan seperti penderita insomnia, kontrol luka, panas dan demam biasa.

Uji hubungan yang dilakukan untuk mengetahui hubungan ESI dengan Kepuasan Pasien yaitu Uji Spearman. Uji ini dilakukan pada variabel dengan skala data ordinal. Hasil yang didapatkan setelah dilakukan uji spearman Kategori ESI dengan variabel Tingkat Kepuasan pasien, diperoleh hasil sig. yaitu 0,147 sehingga nilai sig $>0,05$. Hal ini menunjukkan bahwa tidak terdapat hubungan penetapan ESI dengan kepuasan pasien. Sehingga dalam proses penetapan ESI, baik pasien termasuk 
dalam triage 1 maupun 2 maupun lainnya tidak ada keterkaitannya dengan pasien puas atau tidak puas dengan pelayanan tersebut.

\section{SIMPULAN}

Instalasi Gawat Darurat merupakan pelayanan utama di rumah sakit yang bertujuan untuk melakukan pertolongan pertama pada pasien yang masuk. IGD Rumah Sakit Sido Waras menggunakan konsep ATS yaitu konsep triage atau ESI yang berasal dari Australia. Konsep triage ini mengedepankan pada waktu yang dibutuhkan pasien untuk dapat bertahan dari kondisi kesakitannya. Sebanyak 86 pasien sebagian besar pasien termasuk pada kategori pasien level 4 dan 5 yang artinya pasien masih bisa menunggu untuk mendapatkan pelayanan dan tidak mengalami kondisi yang cukup parah. Sehingga dalam penerapannya banyak terjadi komplain atas pelayanan yang diberikan kepada pasien di level ESI 4 dan 5. Setelah dilakukan uji spearman didapatkan bahwa nilai sign $>0,05$ yang menunjukkan bahwa tidak adanya hubungan yang signifikan antara level ESI dengan kepuasan pasien. Untuk meningkatkan pelayanan pada IGD, sebaiknya petugas memberikan pemahaman kepada pasien terkait triage terutama pada pasien level 4 dan level 5 untuk bersabar dalam mendapatkan penanganan. Selain itu juga petugas dapat memberikan petunjuk alur dalam penggolongan triage kepada pasien sehingga pasien lebih mengetahui posisi kondisi kegawat daruratan keadaan pasien.

\section{DAFTAR PUSTAKA}

Arikunto S. (2006). Metodelogi Penelitan. Yogyakarta: Bina Aksara.

Bolk, J. E., Mencl, F., Rijswijck, B. T. F. V., Simons, M. P., Vught, A. B. V. (2007). Validation of the emergency severity index (ESI) in self referred patients in a European emergency department. Emerg Med J. 24: 170-174

Christ, M. (2010). Modern in the emergency department. Deutsches Arzteblatt international, 107 (50), pp.892-8.

Esther \& Bhuiya. (2009). Wait Time for Treatment in Hospital Emergency Departements. NCHS Data Publication. www.cdc.gov

Gilboy, N., Tanabe, P., Travers, D., Rosenau, A. M. (2011). Emergency Severity Index (ESI); A Triage Tool for Emetgency Department Care Version 4. AHRQ Publication. www.ahrq.gov

Goestsch, D.L and S.Davis. (2005). Introduction to Total Quality : Quality, Productivity, Competitiveness, Englewood Clifs, N J. Pretince Hall International, Inc.

Jerrard, David. (2012). How Long Are Patients Willing to Wait in the Emergency Department Before Leaving Without Being Seen?: University of Maryland. Virginia.

Kelly, AE. (2005). Relationships in emergency care, Topics in Emergency Medicine, Vol 27, No 3, pp.192-197.

Kementerian Republik Indonesia. (2012). Pedoman Teknis Bangunan Rumah Sakit IGD Depertemen Kesehatan RI Tahun 2012.

Kurniasari, Regina. (2016). Analisis Hubungan Pelayanan dengan Kepuasan Pasien (Studi di IGD Rumah Sakit Sido Waras). Universitas Airlangga.

Mace, S.E. \& Mayer, T.A. (2008). Chapter 155 Triage. In Jill M.Baren et., eds Pediatric Emergency Medicine. Philadephia: Elsevier Helath Sciences, pp.1087-1096.

Sugiyono. (2010) Metode Penelitian Pendidikan (Pendekatan Kuantitatif, Kualitatif, Dan R\&D. Hal: 6-15. Bandung: Alfabeta.

Supriyanto, S., Ratna, D.W. (2010). Manajemen Mutu Pelayanan Kesehatan. Health Advocacy.Surabaya

Triage Research Team. (2004). Emergency Severity Index (ESI) A Triage Too for Emergency Department Care. AHRQ Publication. No120014. 